Uşak Üniversitesi Sosyal Bilimler Dergisi

$2013,6 / 3$

A. KAHRAMAN

\title{
A Case Study: Language Needs of Electric-Electronics Students
}

Ayhan KAHRAMAN

\begin{abstract}
The main aim of this research was to find out the language needs of Electric-Electronics Engineering students who are studying English at a state university in Turkey. To identify Engineering students' language needs objectively, the following groups of participants were used as informants: Students of Electric-Electronics Engineering, engineers who graduated from the same institution in the last 5 years, and instructors of Electric-Electronics department. One of the most suitable instruments to assess the linguistic needs of these students was a questionnaire. To obtain the validity and reliability of the questionnaire, a pilot version was constructed and carried out with the fourth year secondary program students. All in all, the analysis of Electric-Electronics engineering students' needs described in this study has revealed that there are similarities and differences regarding the opinions among participants. The most important similarity or difference lies under participants' current linguistic wants, lack of language skills and future linguistic needs. It is believed that the findings of this study will provide useful data for language teachers and course designers to train more successful language learners. Consequently, this study might be used for further studies where similar circumstances occur which require a needs assessment.
\end{abstract}

Key words: Language Needs, Needs Analysis, English for Specific Purposes

\section{Özet}

$\mathrm{Bu}$ çalışmanın temel amacı, Mühendislik Fakültesi, Elektrik Elektronik Mühendisliği (EEM) bölümü öğrencilerinin dilsel

*Yrd. Doç. Dr., Dumlupınar Üniversitesi, Fen Edebiyat Fakültesi, Batı Dilleri ve Edebiyatı Bölümü 
Uşak Üniversitesi Sosyal Bilimler Dergisi

$2013,6 / 3$

A. KAHRAMAN

gereksinimlerini ortaya koymaktır. EEM öğrencilerinin dilsel gereksinimlerini tarafsızca ortaya koyabilmek için farklı üç denek gurubu kullanılmıştır: Türkiye'deki bir devlet üniversitesinin Mühendislik Fakültesi EEM öğrencileri, bölümden son 5 yılda mezun olmuş mühendisler ve bölüm öğretim elemanları. İlgili öğrencilerin dilsel gereksinimlerini ölçmek için kullanılabilecek en uygun araçlardan birisi ankettir. Bu nedenle oluşturulan pilot anketin geçerlik ve güvenirliliğini dördüncü sınıf ikinci öğretim öğrencileri ile sağlanmıştır. Verilerin analizi denekler arasında benzer görüşlerin olduğu kadar farklı görüşlerin de olduğunu ortaya koymaktadır. Kısacası; deneklerin şu an ki gereksinimleri, dil becerilerindeki eksiklikleri ve meslek hayatlarında ihtiyaç duyabilecekleri gereksinimler açısından farklılıklar üç ana başlıkta toplanmaktadır. Bu çalışmanın gereksinim analizinin kullanılacağı diğer araştırmalara ve yabancı dil öğretiminde program hazırlayacak araştırmacı ve öğretmenlere yardımcı olacağ düşünülmektedir. Sonuç olarak bu çalışma, gelecekteki gereksinim analizi gerektiren çalışmalara önemli bir temel oluşturacaktır.

Anahtar Kelimeler: Dil gereksinimi, gereksinim analizi, belirli amaçlı yabancı dil

\section{Introduction}

The English language has become, especially since World War II, the most important language in the world for international communication. It is also the main language used in the international scientific and technical community. As a result, the last 30 years or so have seen the emergence of special English courses for non-native speakers which have been concerned, mainly, with teaching English to science and technology students (Walsh, 1982:143). An important reason for the emergence of these special courses has been the demand from the Third World countries for the scientific and technical knowledge of the advanced industrialized countries. Governments, educational institutions, and private companies in many parts of the world have correctly perceived the connections between the English language and science or technology.

Hutchinson and Waters (1987:21) named these special courses as English for a Specific Purposes (ESP) and defined them, as an approach to 
Uşak Üniversitesi Sosyal Bilimler Dergisi

$2013,6 / 3$

A. KAHRAMAN

language learning, which is based on learner needs. Thus, the question of "Why do these learners need to learn English?" should be the starting point to any course in English. The related literature defines the term "need" as "a gap or measurable discrepancy between a current state of affairs and a desired future state" (Bosher and Smalkoski, 2002:59; Berwick (1989:52). Moreover, while designing an ESP course, the first step is to analyze the needs of the learners so that the course will include the necessary linguistic and conceptual knowledge and skills that the learners need to learn (Hutchinson and Waters, 1987:21). In conclusion, needs analysis shows "the gap between what is and what should be" (Brindley 1989:65).

The Faculty of Engineering consists of six departments and ElectricElectronics Engineering is one of them. These departments have different disciplines and branches and their students' have to take compulsory English courses; English I and English II. The main aim in teaching English is to foster a creative use of some skills to meet specific needs and interests and to increase students' attitudes and abilities at getting information and to develop interest and motivation (Öner, 1983; Okçu, 1986; Akar, 1999; Ertit, 1999). For example, it is observed that Electric-Electronics Engineering students have to read definitely in English for their courses. More importantly, they may need to read for their careers after graduation.

So, the syllabus of the English courses, English I and English II, should take Electric-Electronics Engineering students' linguistic wants and needs into consideration. While designing these English courses, learners' needs have been of primary importance but considering only students' needs may not serve sufficient data. Engineers' and content course instructors' opinions about the learners' needs should also be taken into consideration. For instance, today in Turkey, many employers expect their employees to have a good command of foreign languages- especially English- as well. Also, content course teachers state that their students have to acquire at least some basic reading strategies and that they should be encouraged to keep up with the Engineering literature and in the subjectrelated areas.

Therefore, this study tries to specify students' linguistic needs by handing out questionnaires to content course teachers, students and former students of the department, i.e. engineers. It is necessary to analyse learners', 
Uşak Üniversitesi Sosyal Bilimler Dergisi

$2013,6 / 3$

A. KAHRAMAN

engineers' and content course teachers' views to state the required linguistic and conceptual knowledge that the learners need to learn in their academic studies and/or vocational fields. As teachers, we have insufficient information about engineering students' use of the target language outside the university and as researchers, we have less information concerning the type of situations in which engineering students might need the language after graduation.

Thus, it is very important to make an extensive survey and compare students' linguistic wants with engineers' and content course teachers' opinions since comparing participants' views will indicate the needs and provide useful data for efficient curriculum designs in and outside the department.

It was the realization of above-mentioned thoughts that stimulated us to the design of a needs analysis survey at the Electric-Electronics Engineering Department. The results of the investigation might give useful data for current approach (es) and these can be used in re-structuring the current foreign language curriculum at the E-E Engineering Department. Although the actual language needs of Electric-Electronics Engineering students might vary regionally, the applied process of questionnaire design, validation and data analysis can serve as a model or example for other institutions as well. This study tries to answer the following research questions:

1. For what purpose do Electric-Electronics Engineering students learn English?

2. Which language skills do the Electric-Electronics Engineering students mostly need?

3. Do the students in different years show any similar tendency regarding their language needs?

4. Do the students, graduates and subject specialist instructors show any different tendencies regarding students' language needs?

\section{Literature Review}

Having emerged in 1960s, English for Specific Purposes (ESP) is not a new term in the field of ELT. Peter Strevens in 1964, Jack Ewer in 1969 and John Swales in 1971 were operating on the basic principle that the English of 
Uşak Üniversitesi Sosyal Bilimler Dergisi

$2013,6 / 3$

A. KAHRAMAN

electrical engineering constituted a specific register different from that of general English. The aim of the analysis was to identify the grammatical and lexical features of these registers (cited in Hutchinson and Waters, 1987:9). In fact, as Ewer and Latorre's syllabus shows (1969), register analysis revealed that in the sentence grammar of scientific English was a tendency to favor particular forms such as the present simple tense, the passive voice and nominal compounds and, although the existence of a term such as "scientific language", the study confirmed that these grammatical and lexical features are not different from the "general English". However, whatever you call it (general English, ESP, EOP...) any course needs a needs analysis (cited in Hutchinson and Waters, 1987:10). As Robinson (1991:7) has mentioned, the aim of such analyses is to produce a syllabus, which gives high priority to the language forms that students would meet in their science studies.

Ewer and Hughes-Davies (1971), for example, have compared the language of the texts their science students had to read with the language of some widely used school textbooks. They found that the school textbooks neglected some of the language forms commonly found in science texts; for example, compound nouns, passive, conditionals, modal verbs. Their conclusion was that the ESP course should give precedence to these forms (cited in Hutchinson and Waters, 1987:10). As asserted by Walsh (1982:14347) this suggestion is important since scientific and technical knowledge is communicated mainly through scientific documents and it seems to be obvious that science texts are very complicated documents not only for nonnative students but aolso for natives.

Shortly, many readers, natives or non-natives, at some stage in their reading lives will be in touch with complex scientific texts. This complexity, better said the rhetorical and conceptual part of a scientific text causes some problems not only for language learners but also for EFL/ESL teachers. For instance, Selinker (1979:191-92) describes in his research project involving the study of an academic article in Genetics by a group of ESL teachers and discussion of their questions by a specialist informant. What emerged was that teachers were not only ignorant of the meaning of technical terms and they could not identify when "common language words" were being used technically. They misunderstood also the meaning "in context" of certain 
Uşak Üniversitesi Sosyal Bilimler Dergisi

$2013,6 / 3$

A. KAHRAMAN

model verbs, connectives and even punctuation, because of their lack of specialist knowledge, did not in fact realize.

Cause of the above-mentioned reasons, many linguists as Dresdner (1981:243) attempts to show why the teaching of scientific English at the university level is important and to spell out an approach as to how this type of English can be effectively taught. He showed the Chilean university students who are inevitable faced with textbooks in English. If the literature on scientific topics is in English, it is inevitable to teach scientific English. For the second question, he suggested to sequence the characteristics of scientific English, such as use of the passive voice, functional shifts, special compounds etc (Dresdner, 1981:243-46).

Lutoslawska (1981:247-49) also made similar suggestions and shared her experiences at the university of Krakow and supports Dresdner with the idea that technical university students should have scientific English courses because they need the ability to read technical texts, books or articles and prepare papers for seminars. That means they should have scientific knowledge for reading or dealing with such texts. It is obvious that technical texts not only employ a specialized vocabulary; they also use special structures (the passive voice, etc.) that occur more often in technical than in literary texts.

Wiriyachitra's study (1982:148-51) at Prince of Songkla University was about reinforcing the development of reading ability. Since scientific materials are saturated with ideas, they require careful and thorough reading. A proficient reader must coordinate a number of skills: he must read rapidly as well as with a thorough understanding of the subject matter.

Many factors, however, are considered when designing a course curriculum or course material for a second language classroom. Identifying the learners' needs, assessing the availability of materials and their appropriateness for the learners, and considering the kind of teaching and learning are some of these factors (Jordan, 1997). Hutchinson and Waters' (1987:3), for example, outline of "A learning-centered approach to ESP" starts with an overview of the origins and development of ESP and considers the question of how ESP fits into the general landscape of English Language Teaching (see Figure1 below). Then, they look at basic principles and techniques in course design and ask how a teacher or course designer 
Uşak Üniversitesi Sosyal Bilimler Dergisi

$2013,6 / 3$

A. KAHRAMAN

creates a course to fit the needs of a particular group of learners. The next step is concerned with the practical applications of the course design in the form of a syllabus, materials, methodology and assessment. They finally consider the role of the ESP teacher and provide information about resources to help the teacher.

In conclusion, as Nunan (1999:148) has suggested the content of language courses should reflect the purposes for which the students learn the language. Rather than fitting students to courses, courses should be designed to fit students. As teachers of this department with 10 years of experience, we had implicit views of what students need to know in order to function effectively in academic settings. Nevertheless, we knew very little about the purposes that Electric-Electronics students use the target language for outside the university, and had even less information concerning the type of situations in which students might need the language after graduation. Considering the above mentioned reasons, this study has aimed to investigate the linguistic needs of the students of the Electric-Electronics Engineering Department. 
Uşak Üniversitesi Sosyal Bilimler Dergisi

$2013,6 / 3$

A. KAHRAMAN

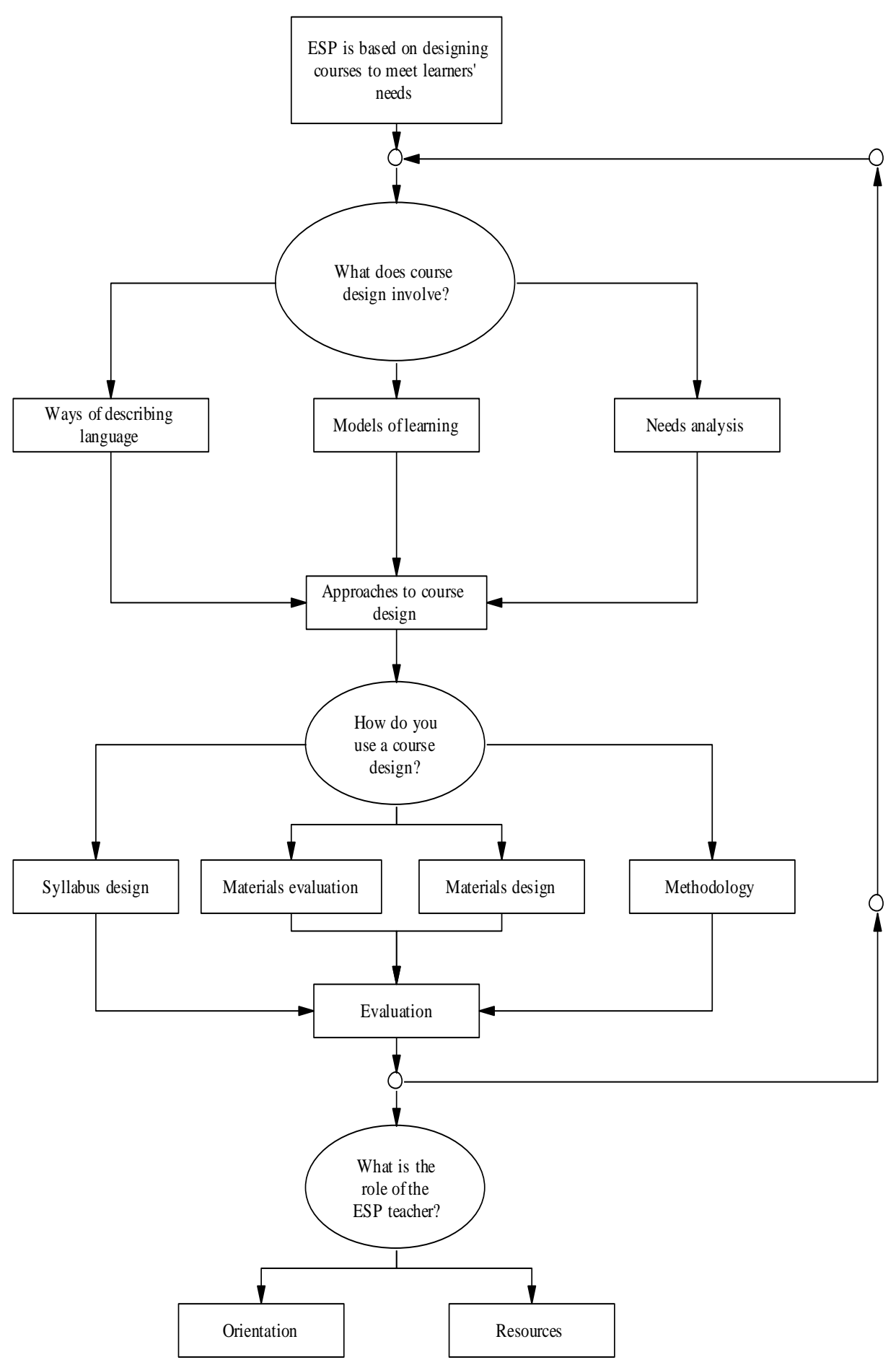

Figure1 :A Learning-Centred Approach to ESP by Hutchinson and Waters (1987) 
Uşak Üniversitesi Sosyal Bilimler Dergisi

$2013,6 / 3$

A. KAHRAMAN

\section{Methodology}

\section{Participants}

Learners' needs are unquestionably important in needs assessment but asking or finding out only learners' needs may not be enough for course designers. As Wiriyachitra (1982:149) states, the subject specialist instructors are also a very important resource people during all phases of the course development. The design of the syllabus from the needs profile, with the help of the subject specialists, make the language program more meaningful and useful to the learners. However, as Kormos (2002:517-42) also mentioned, subject specialists and language teachers were able to know very little about the purposes engineering students use the target language for outside the university and as researchers we had less information concerning the type of situations in which engineering students might need the language after graduation, since they can attend a wide variety of working places. Therefore, the participants of this research were selected from three different subject groups: Students, graduates and subject specialist instructors. The first and the largest group were composed of all the 155 undergraduate students of the Electric-Electronics Engineering Department - 55 freshmen, 30 sophomores, 40 juniors and 30 seniors. The second group consists of 14 content course instructors of the E-E department and the last group involves 20 engineers, randomly chosen but graduated from this department in the last five years and work in private sector or for the government.

Participants were told that they would take part in a study in order to develop the language program and assured of the confidentiality of the information they would report in their questionnaires.

\section{Development of the Instrument}

The main instrument used to assess linguistic needs of the E-E Engineering students is a questionnaire. For source of items, we did not only make use of existing questionnaires (by Salem, 1986; Pişiren, 1996; Ertaş, 1998; Akar, 1999; Seçen, 2001; Bosher and Smalkoski, 2002; Kormos et al., 2002) but collected preliminary qualitative data from E-E engineering students studying at the state university. Fifty freshmen students of E-E 
Uşak Üniversitesi Sosyal Bilimler Dergisi

$2013,6 / 3$

A. KAHRAMAN

Engineering Department were asked for itemizing their thoughts according to these questions:

1. What is Electric-Electronics Engineering students' current purpose of learning English?

2. What are Electric-Electronics Engineering students' linguistic necessities?

3. What kinds of advantages will "an appropriate" language education provide for Electric-Electronics Engineering students?

The obtained categories or items together with those found in the literature were used to compile the first version of the questionnaire namely the pilot version. The pilot questionnaire was prepared in Turkish for the purpose of better understanding. After the pilot version of the questionnaire was compiled, it was submitted to tests of validity and reliability. Firstly, in order to ensure that the respondents interpret the questions in the same way as intended by the researcher, and to see if they fully understand the questions, the technique of verbal reporting-testing -Response Validity- was used (Alderson and Banerjee, 1996, cited in Kormos et al., 2002). Five randomly chosen E-E Engineering students from the target population were asked to think aloud while filling in the questionnaire. The pilot version of the questionnaire is handed out to 20 faculty members at two different state universities for checking the "face validity". We had 13 very valuable feedbacks. In the light of experts' feedback, itemization results and the pilot study, the final version of the questionnaire, i.e. student questionnaire, is constructed (see Appendix B). Finally, it is intended to check the reliability so a pilot run with the first version of the questionnaire was conducted. Twenty-nine second education senior class E-E Engineering students answered the pilot questionnaire. For reliability analysis Cronbach's Alpha and Split-Half methods have been used and the results indicated as $\alpha=$, $7563 ; p=, 000$.

\section{Instrument}

The results of piloting of the questionnaire, experts' feedback and itemization results led to some changes and revisions towards the final 
Uşak Üniversitesi Sosyal Bilimler Dergisi

$2013,6 / 3$

A. KAHRAMAN

version of the questionnaire. That is, questions and items were revised and refined relying on the feedback. After the final reshaping, the student questionnaire was administered. This modification did not affect the reliability of the questionnaire. Standardized item Alpha $\alpha=, 7844 ; \mathrm{p}=000$.

The Student questionnaire was reverbalized when used with former students of this department i.e. engineers and content course teachers, but only to the extent necessary to make it appropriate for the target population.

These above-mentioned questionnaires consist of three parts:

Part I contains demographical information (12 questions) about participants' age, sex, education, etc. However, while analyzing data, personal information was not taken into consideration.

Part II contains five rank-order questions and seeks students' present and future needs. Participants had to list different choices by ranking in order of importance or necessity.

The third part of the questionnaires consisted of 15 Lickert-scale type questions and seeks information about what a foreign language course should provide E-E Engineering students. Participants had to choose the most suitable item for each statement, which ranged from strongly agree (1) to strongly disagree (5).

\section{Data collection \& Analysis}

The main instrument used to asses the linguistic needs of the Electric-Electronics Engineering students was a questionnaire and administered primarilyat the Department of Electric-Electronics Engineering in May 2003. Electric-Electronics Engineering students' questionnaire was applied in the subjects' classroom at their regular scheduled class time. That means the questionnaire was administered in four separate lecture sessions to a total of 155 undergraduate students - the freshmen, sophomore, junior and senior classes. Questionnaires were also given to 14 content course teachers and 20 engineers. No time limit was imposed, but respondents took between 15 and 20 minutes to complete the questionnaire.

Using Özdamar's valuable book about statistical analysis written in 1999 and the Statistical Package Program for Social Sciences (SPSS), the questionnaire results were computer-coded and analyzed. This study was 
Uşak Üniversitesi Sosyal Bilimler Dergisi $2013,6 / 3$

A. KAHRAMAN

descriptive in nature and descriptive statistics such as percentages was employed to analyse the data.

\section{Results}

Concerning students', instructors' and engineers' views on the purpose of learning English, this section presents the data in frequencies and percentages.

\section{Purpose of Learning English}

First of all, freshmen were asked about what their purpose of learning English was and required to choose 3 of the items according to their importance.

Table 1: Purpose of learning English (rank 1)

\begin{tabular}{|c|c|c|c|c|c|c|c|c|c|c|c|c|c|}
\hline & \multicolumn{3}{|l|}{ Freshmen } & \multicolumn{2}{l|}{ Sophomores } & \multicolumn{2}{l|}{ Juniors } & \multicolumn{2}{l|}{ Seniors } & \multicolumn{2}{l|}{ Engineers } & \multicolumn{2}{|l|}{$\begin{array}{c}\text { Instructo } \\
\text { Is }\end{array}$} \\
\cline { 2 - 14 } & F & $\%$ & F & $\%$ & F & $\%$ & F & $\%$ & F & $\%$ & F & $\%$ \\
\hline 1 & 10 & 18,2 & 4 & 13,3 & 7 & 17,5 & 10 & 33,3 & 5 & 25,0 & 2 & $\begin{array}{c}14 \\
3\end{array}$ \\
\hline 2 & - & - & 1 & 3,3 & - & - & 2 & 6,7 & 1 & 5,0 & - & - \\
\hline 3 & $\mathbf{2 6}$ & $\mathbf{4 7 , 3}$ & $\mathbf{1 6}$ & $\mathbf{5 3 , 3}$ & $\mathbf{2 3}$ & $\mathbf{5 7 , 5}$ & $\mathbf{1 1}$ & $\mathbf{3 6 , 7}$ & 3 & 15,0 & $\mathbf{8}$ & $\mathbf{5 7}$ \\
& & & & & & & & & & & & $\mathbf{1}$ \\
\hline 4 & 10 & 18,2 & 8 & 26,7 & 5 & 12,5 & 4 & 13,3 & 5 & 25,0 & 3 & $\begin{array}{c}21 \\
4\end{array}$ \\
\hline 5 & - & - & - & - & - & - & - & - & 1 & 5,0 & - & - \\
\hline 6 & 3 & 5,5 & - & - & 2 & 5,0 & 1 & 3,3 & - & - & - & - \\
\hline 7 & 2 & 3,6 & - & - & - & - & - & - & 1 & 5,0 & 1 & 7,1 \\
\hline 8 & - & - & - & - & - & - & - & - & - & - & - & - \\
\hline 9 & 3 & 5,5 & - & - & 2 & 5,0 & - & - & 2 & 10,0 & - & - \\
\hline 10 & - & - & - & - & - & - & - & - & - & - & - & - \\
\hline 11 & 1 & 1,8 & 1 & 3,3 & - & - & 1 & 3,3 & 1 & 5,0 & - & - \\
\hline 12 & - & - & - & - & 1 & 2,5 & - & - & - & - & - & - \\
\hline 13 & - & - & - & - & - & - & 1 & 3,3 & 1 & 5,0 & - & - \\
\hline
\end{tabular}


Uşak Üniversitesi Sosyal Bilimler Dergisi

$2013,6 / 3$

A. KAHRAMAN

\begin{tabular}{|c|c|c|c|c|c|c|c|c|c|c|c|c|}
\hline Total & 55 & 100,0 & 30 & 100,0 & 40 & 100,0 & 30 & 100,0 & 20 & 100,0 & 14 & $\begin{array}{r}10 \\
0,0\end{array}$ \\
\hline
\end{tabular}

As shown above in Table 1, 26 out of 55 freshmen (47,3\%) stated the 3rd item as the most important one. That means, nearly half of the freshmen pointed out that proficiency in English will provide advantages in their professional lives. $53,3 \%$ of the sophomores, $57,5 \%$ of the third-year students and $36,7 \%$ of the fourth-year students ranked also the 3rd item in the 1st place. Shortly, the majority of the students remarked similar views upon the purpose of learning English. This leads us to the conclusion that more than half of the students' think that having a good English knowledge will provide advantages in their professional lives. That is, they estimate that having a good knowledge of English will provide them with language benefits such as finding a better job easily, getting better salary and promotion or simply visiting foreign countries.

Similarly, a high response frequency can be seen by instructors. When their experience and observation about their students' purpose of learning English were asked, 57,1\% of the instructors ranked also the 3rd item in the first place as the most important one. Thatis, the instructors share a common idea and state that Electric-Electronics engineering students have been learning English for individual benefits.

Engineers' preferences, however, were not similar to those of the students' and instructors' when we compared the responses for the purpose of learning English. 25\% of the engineers were more interested in the global side of English and pointed out that their aim of learning English is because of its use as the universal language. The other 25\% emphasized the essentialness of English in the area of engineering. It seems to be that engineers' most important purpose of learning English is different from students' and instructors'.

Participants, except engineers, highlighted the 4th item as the second most important one when their opinion about the purpose of learning English was asked. That is $32,7 \%$ of freshmen, $40 \%$ of sophomores, $45 \%$ of juniors, $46,7 \%$ of seniors and $42,9 \%$ of instructors who supported the point that English is very necessary for engineering area. On the other side, engineers again supported a global view. They highlighted the point that the 
Uşak Üniversitesi Sosyal Bilimler Dergisi

$2013,6 / 3$

A. KAHRAMAN

purpose of learning English is necessary for following the rapid changing technological developments and advocated the occupational purpose as the other participants stated earlier as their uppermost view. In short, data indicates that there is a need to develop language skills for E-E Engineering students for use within professional setting.

\section{Language Wants of E-E Engineering Students}

In the second section of the research, students were asked which language skills they would like to have mastered the most before graduation.

Table 2: Frequency of language wants before graduation (rank 1)

\begin{tabular}{|c|c|c|c|c|c|c|c|c|c|c|c|c|}
\hline \multirow{2}{*}{$\begin{array}{c}\text { Item } \\
\mathrm{s}\end{array}$} & \multicolumn{2}{|c|}{ Freshmen } & \multicolumn{2}{|c|}{$\begin{array}{c}\text { Sophomore } \\
\text { s }\end{array}$} & \multicolumn{2}{|c|}{ Juniors } & \multicolumn{2}{|c|}{ Seniors } & \multicolumn{2}{|c|}{ Engineers } & \multicolumn{2}{|c|}{ Instructors } \\
\hline & F & $\%$ & $F$ & $\%$ & F & $\%$ & F & $\%$ & F & $\%$ & $\mathrm{~F}$ & $\%$ \\
\hline 1 & 37 & 67,3 & 17 & 56,7 & $\begin{array}{l}2 \\
1 \\
\end{array}$ & 52,5 & $\begin{array}{l}1 \\
6 \\
\end{array}$ & 53,3 & 16 & 80,0 & 5 & 35,7 \\
\hline 2 & 8 & 14,5 & 9 & 30,0 & $\begin{array}{l}1 \\
3\end{array}$ & 32,5 & 8 & 26,7 & 1 & 5,0 & 1 & 7,1 \\
\hline 3 & 1 & 1,8 & - & - & - & - & 1 & 3,3 & - & - & - & - \\
\hline 4 & 2 & 3,6 & 2 & 6,7 & 2 & 5,0 & 3 & 10,0 & - & - & 3 & 21,4 \\
\hline 5 & 5 & 9,1 & 1 & 3,3 & 3 & 7,5 & 2 & 6,7 & 2 & 10,0 & 5 & 35,7 \\
\hline 6 & 1 & 1,8 & - & - & - & - & - & - & 1 & 5,0 & - & - \\
\hline 7 & 1 & 1,8 & 1 & 3,3 & 1 & 2,5 & - & - & - & - & - & - \\
\hline Total & 55 & $\begin{array}{c}100, \\
0\end{array}$ & 30 & 100,0 & $\begin{array}{l}4 \\
0\end{array}$ & $\begin{array}{c}100, \\
0\end{array}$ & $\begin{array}{l}3 \\
0\end{array}$ & $\begin{array}{c}100, \\
0\end{array}$ & 20 & $\begin{array}{c}100 \\
0\end{array}$ & 14 & $\begin{array}{c}100, \\
0\end{array}$ \\
\hline
\end{tabular}

As seen above in Table 2, 67,3\% of freshmen, $56,7 \%$ of sophomores, $52,5 \%$ of juniors and 53,3\% seniors would like upper mostly to speak English fluently. Moreover, nearly all of the engineers (80\%) agree on the abovementioned item, so their uppermost choice is also speaking. When, on the other side, the instructors were asked, $35,7 \%$ of them agreed with the rest of the population but another $35,7 \%$ clarified the 5 th item as the most important one; namely, students of E-E engineering department should be 
Uşak Üniversitesi Sosyal Bilimler Dergisi

$2013,6 / 3$

A. KAHRAMAN

able to translate from English to Turkish without any difficulty. It is obvious that they think their students should be able to speak English fluently but on the other hand they emphasize the importance of transferring of knowledge which can only be achieved by translation. For example, Walsh (1982:143), in his study, underlined the fact that foreign governments, educational institutions and private companies in many parts of the world have correctly perceived the connections between the English language and science or technology. Most observers would agree that scientific and technical knowledge is communicated through printed documents and to get this knowledge, people should be able to read thoroughly and do a "relevant" translation.

Most of the student participants' secondary choice was based on reading newspapers, magazines, books and papers in English but 38,2\% of freshmen gave secondary importance to writing vocational or personal letters. On the other hand, engineers' second most important want was related with listening skills. They want to watch TV and listen to the radio programs without having comprehension problems. As a conclusion, instructors state three different items as their second most important ones with an equal percentage. That is $21,4 \%$ of instructors gave secondary importance to writing skills such as writing vocational or personal letters (Item 2). Another 21,4\% highlighted the importance of reading skills; reading newspapers, magazines, books and papers in English (Item 4). The last group of instructors $(21,4 \%)$ mentioned the translation ability as the second most important, especially translating from Turkish into English (Item 6).

\section{Present Linguistic Lacks of E-E Engineering Student}

Participants were also asked about their present linguistic lacks since such information is important for understanding the learning needs of each student in class, their strengths as well as areas of greatest need (Bosher, 2002:67).

Table 3. Frequency of present linguistic lacks (rank 1) 
Uşak Üniversitesi Sosyal Bilimler Dergisi

$2013,6 / 3$

A. KAHRAMAN

\begin{tabular}{|c|c|c|c|c|c|c|c|c|c|c|c|c|}
\hline \multirow{2}{*}{$\begin{array}{c}\text { Item } \\
\mathrm{s}\end{array}$} & \multicolumn{2}{|c|}{ Freshmen } & \multicolumn{2}{|c|}{$\begin{array}{c}\text { Sophomore } \\
\text { s }\end{array}$} & \multicolumn{2}{|c|}{ Juniors } & \multicolumn{2}{|c|}{ Seniors } & \multicolumn{2}{|c|}{ Engineers } & \multicolumn{2}{|c|}{ Instructors } \\
\hline & F & $\%$ & $\mathrm{~F}$ & $\%$ & F & $\%$ & F & $\%$ & F & $\%$ & F & $\%$ \\
\hline 1 & 6 & 10,9 & 1 & 3,3 & 6 & 15,0 & 2 & 6,7 & 1 & 5,0 & 2 & 14,3 \\
\hline 2 & 6 & 10,9 & 4 & 13,3 & 5 & 12,5 & 7 & 23,3 & 2 & 10,0 & 4 & 28,6 \\
\hline 3 & 25 & 45,5 & 13 & 43,3 & $\begin{array}{l}2 \\
1\end{array}$ & 52,5 & $\begin{array}{l}1 \\
4\end{array}$ & 46,7 & 11 & 55,0 & 1 & 7,1 \\
\hline 4 & 1 & 1,8 & 1 & 3,3 & 1 & 2,5 & 2 & 6,7 & 1 & 5,0 & - & - \\
\hline 5 & 3 & 5,5 & 3 & 10,0 & 1 & 2,5 & - & - & 2 & 10,0 & 2 & 14,3 \\
\hline 6 & 2 & 3,6 & 1 & 3,3 & 1 & 2,5 & - & - & 2 & 10,0 & 1 & 7,1 \\
\hline 7 & 2 & 3,6 & 1 & 3,3 & 2 & 5,0 & 3 & 10,0 & 1 & 5,0 & 1 & 7,1 \\
\hline 8 & 4 & 7,3 & - & - & 2 & 5,0 & 1 & 3,3 & - & - & 1 & 7,1 \\
\hline 9 & 3 & 5,5 & 5 & 16,7 & 1 & 2,5 & - & - & - & - & 1 & 7,1 \\
\hline 10 & - & - & - & - & - & - & - & - & - & - & 1 & 7,1 \\
\hline 11 & 1 & 1,8 & - & - & - & - & 1 & 3,3 & - & - & - & - \\
\hline 12 & 2 & 3,6 & 1 & 3,3 & - & - & - & - & - & - & - & - \\
\hline Total & 55 & $\begin{array}{c}100 \\
0\end{array}$ & 30 & 100,0 & $\begin{array}{l}4 \\
0\end{array}$ & $\begin{array}{c}100, \\
0\end{array}$ & $\begin{array}{l}3 \\
0\end{array}$ & $\begin{array}{c}100, \\
0\end{array}$ & 20 & $\begin{array}{c}100 . \\
0\end{array}$ & 14 & $\begin{array}{c}100 \\
0\end{array}$ \\
\hline
\end{tabular}

As shown in Table 3, 45,5\% of freshmen, $43,3 \%$ of sophomores, $52,5 \%$ of juniors, 46,7 of seniors and $55 \%$ of engineers wish that they could speak English fluently. Data, however, shows that only one of the instructors believes that speaking fluently is the most important need of the engineering students but with $28,6 \%$, highlighted the importance of translation from Turkish into English as their uppermost need.

When students' secondary choices were analysed, it can be seen that they do not have common decision. For instance, 20\% of freshmen and 20\% of sophomores believe that they could not translate well from English into Turkish (Item 2). On the other hand, engineers' (25\%) second most important lack is related with writing skills. That is, they wish they could state their thoughts in English (Item 11). Finally, instructors believe by 35, $7 \%$ that understanding-reading texts in English (item 5) is their students second most important need.

All in all, considering students' lacks in different years, there is no consensus regarding the second and third choices. That means they were 
Uşak Üniversitesi Sosyal Bilimler Dergisi

$2013,6 / 3$

A. KAHRAMAN

focused on the first most important need; namely on the speaking skills. However, it should not be forgotten that this desire for speaking might also be related with inadequate former English courses they had taken.

\section{Future Linguistic Needs of E-E Engineering Students}

In this section of the research, students were asked about the language areas which they intend to use English when they will do their jobs in the future; Question 17. The same question was administered to 20 engineers and 14 content course instructors so that the expectations of current students and the frequency of engineers could be compared. As Kormos (2002:520) has also mentioned, subject specialists and language teachers might know very little about the purposes engineering students use the target language for outside the university and as researchers we have less information concerning the type of situations in which engineering students might need the language after graduation, since they can attend a wide variety of working places. Consequently, it is very crucial to make an extensive survey and compare students' linguistic wants and needs with those of the graduates of this department.

Table 4. Frequency for linguistic needs (rank 1)

\begin{tabular}{|c|c|c|c|c|c|c|c|c|c|c|c|c|}
\hline \multirow{2}{*}{$\begin{array}{c}\text { Item } \\
\mathrm{s} \\
\end{array}$} & \multicolumn{2}{|c|}{ Freshmen } & \multicolumn{2}{|c|}{$\begin{array}{c}\text { Sophomore } \\
\mathrm{s}\end{array}$} & \multicolumn{2}{|c|}{ Juniors } & \multicolumn{2}{|c|}{ Seniors } & \multicolumn{2}{|c|}{ Engineers } & \multicolumn{2}{|c|}{ Instructors } \\
\hline & F & $\%$ & $\mathrm{~F}$ & $\%$ & F & $\%$ & F & $\%$ & F & $\%$ & F & $\%$ \\
\hline 1 & 26 & 47,3 & 13 & 43,3 & $\begin{array}{l}2 \\
1\end{array}$ & 52,5 & $\begin{array}{l}1 \\
2\end{array}$ & 40,0 & 5 & 25,0 & 1 & 7,1 \\
\hline 2 & 6 & 10,9 & 1 & 3,3 & 2 & 5,0 & 2 & 6,7 & 1 & 5,0 & 1 & 7,1 \\
\hline 3 & 6 & 10,9 & 6 & 20,0 & 4 & 10,0 & 2 & 6,7 & 11 & 55,0 & 7 & 50,0 \\
\hline 4 & 4 & 7,3 & 2 & 6,7 & 2 & 5,0 & 7 & 23,3 & 1 & 5,0 & 1 & 7,1 \\
\hline 5 & 3 & 5,5 & 2 & 6,7 & 3 & 7,5 & 1 & 3,3 & 2 & 10,0 & 2 & 14,3 \\
\hline 6 & 7 & 12,7 & 4 & 13,3 & 7 & 17,5 & 3 & 10,0 & - & - & 2 & 14,3 \\
\hline 7 & 1 & 1,8 & - & - & - & - & - & - & - & - & - & - \\
\hline 8 & 2 & 3,6 & 1 & 3,3 & 1 & 2,5 & 1 & 3,3 & - & - & - & - \\
\hline 9 & - & - & 1 & 3,3 & - & - & 2 & 6,7 & - & - & - & - \\
\hline 10 & - & - & - & - & - & - & - & - & - & - & - & - \\
\hline
\end{tabular}


Uşak Üniversitesi Sosyal Bilimler Dergisi

$2013,6 / 3$

A. KAHRAMAN

\begin{tabular}{|c|c|c|c|c|c|c|c|c|c|c|c|c|}
\hline Total & 55 & $\begin{array}{c}100, \\
0\end{array}$ & 30 & 100,0 & $\begin{array}{l}4 \\
0\end{array}$ & $\begin{array}{c}100 \\
0\end{array}$ & $\begin{array}{l}3 \\
0\end{array}$ & $\begin{array}{c}100 \\
0\end{array}$ & 20 & $\begin{array}{c}100 . \\
0\end{array}$ & 14 & $\begin{array}{c}100, \\
0\end{array}$ \\
\hline
\end{tabular}

As shown above in Table 4, 47,3\% of freshmen, 43,3 of sophomores, $52,5 \%$ of juniors and $40 \%$ of seniors, that is nearly half of the total number of the students, believe that their upper most language use in the future will be speaking skills (item 1). However, engineers and instructors do not seem to share the same opinion. Results of question 17 shows us that their upper most need is stated as "reading and comprehending" the publications in English thoroughly (item 3). Walsh (1982:143) claims that most observers would agree that scientific and technical knowledge is communicated mainly through printed documents: scientific texts, science textbooks, research papers, technical manuals, and technical handbooks. It is for this reason that textbook readings form an important part of nearly every language course and that so much emphasis is placed on reading-reference skills. He adds that this emphasis on the written word and reading skills is characteristic of ESP courses in many parts of the world. Additionally, engineers' second and third most important needs were also not speaking. $35 \%$ of engineers indicated the need of translating from foreign sources as the 2nd most important need and $40 \%$ of them highlighted surfing in Internet without having any linguistic difficulty as the third one. Concerning the 2nd choices, instructors also have different opinions. 28,6\% of instructors believe that the students' most important need for occupational purpose is "speaking" but only in order to realize his daily or vocational activities (item 2 ). However, another $28,6 \%$ group of instructors clarified the 4 th item as the second most important one; that is instructors think that E-E engineering students need mostly reading skills only in order to obtain information from publications written in English.

Consequently, when students were asked to estimate the most important skill in their future job, nearly half of the E-E engineering students opted again the need for "speaking". That is their most important need at present and in the future seems to be "speaking", but in their professional lives, engineers and instructors do not value speaking skills as one of their most important need. 
Uşak Üniversitesi Sosyal Bilimler Dergisi

$2013,6 / 3$

A. KAHRAMAN

\section{Current Language Uses of E-E Engineering Students}

Informal discussions held with students seemed to suggest that they do not use English very often outside the university. For instance, in their private lives, they rarely watch English language movies, news and hardly ever-read newspapers in English. They also have little chance to communicate with native or non-native speakers of English. Nevertheless, they sometimes translate instruction manuals for family members and acquaintances and chat on the Internet. Question 16, for example, comprises situations in which students use English currently both in and outside the university. Outcomes of question 16 were analysed wholistically. The findings regarding different groups of participants were similar and likewise the groups highlighted two items, ranking under importance the 6th and 4th items sequentially.

Table 5: Current language uses of E-E students (rank 1)

\begin{tabular}{|c|c|c|c|c|c|c|c|c|c|c|c|c|}
\hline \multirow{2}{*}{$\begin{array}{c}\text { Item } \\
\mathrm{s}\end{array}$} & \multicolumn{2}{|c|}{$\begin{array}{c}\text { Freshme } \\
n\end{array}$} & \multicolumn{2}{|c|}{$\begin{array}{c}\text { Sophomore } \\
\text { s }\end{array}$} & \multicolumn{2}{|c|}{ Juniors } & \multicolumn{2}{|c|}{ Seniors } & \multicolumn{2}{|c|}{$\begin{array}{c}\text { Engineer } \\
\mathrm{S}\end{array}$} & \multicolumn{2}{|c|}{ Instructors } \\
\hline & $\mathrm{N}$ & $\%$ & $\mathrm{~N}$ & \begin{tabular}{|l|}
$\%$ \\
\end{tabular} & $\mathrm{~N}$ & $\%$ & $\mathrm{~N}$ & $\%$ & $\mathrm{~N}$ & $\%$ & $\mathrm{~N}$ & $\%$ \\
\hline 1 & 3 & 5,0 & - & - & 1 & 2,5 & 1 & 3,3 & 1 & 5,0 & & - \\
\hline 2 & 1 & 1,8 & 1 & 3,3 & & & & 3,3 & - & - & & 7,1 \\
\hline 3 & 4 & 7,3 & 2 & 6,7 & 2 & 5,0 & 1 & 3,3 & 1 & 5,0 & & - \\
\hline $4^{*}$ & $\begin{array}{c}21 \\
*\end{array}$ & $\begin{array}{c}38,2 \\
*\end{array}$ & 5 & 16,7 & 11 & 27,5 & $\begin{array}{c}11 \\
*\end{array}$ & $\begin{array}{c}36,7 \\
*\end{array}$ & 3 & 15,0 & 3 & 21,4 \\
\hline 5 & 7 & 12,7 & 8 & 26,7 & 4 & 10,0 & 6 & 20,0 & 3 & 15,0 & 3 & 21,4 \\
\hline $6^{*}$ & 15 & 27,3 & $12^{*}$ & $40,0^{*}$ & $\begin{array}{c}20 \\
*\end{array}$ & $\begin{array}{c}50,0 \\
*\end{array}$ & 8 & 26,7 & $\begin{array}{l}12 \\
*\end{array}$ & $\begin{array}{c}60,0 \\
*\end{array}$ & $6^{*}$ & $\begin{array}{c}42,9 \\
*\end{array}$ \\
\hline 7 & 2 & 3,6 & - & - & - & - & 2 & 6,7 & - & - & 1 & 7,1 \\
\hline 8 & 2 & 3,6 & 2 & 6,7 & 2 & 5,0 & - & - & - & - & - & - \\
\hline 9 & - & - & - & - & - & - & - & - & - & - & - & - \\
\hline Total & 55 & $\begin{array}{c}100 \\
0\end{array}$ & 30 & 100,0 & 40 & $\begin{array}{c}100, \\
0\end{array}$ & 30 & $\begin{array}{c}100 \\
0\end{array}$ & 20 & $\begin{array}{c}100 . \\
0\end{array}$ & 14 & $\begin{array}{c}100, \\
0\end{array}$ \\
\hline
\end{tabular}

The results, as seen above in Table 5, indicate that the current use of the language is upper mostly for academic purposes. For instance, 
Uşak Üniversitesi Sosyal Bilimler Dergisi

$2013,6 / 3$

A. KAHRAMAN

instructors (42,9\%), engineers (60\%), juniors (50\%) and sophomores $(40 \%)$ use the English language when keeping up with engineering related publications (item 6). On the other hand, 38,2\% of freshmen and 36,7\% of seniors indicate the importance of keeping up with the developments in the field of engineering where English language is mostly used (item 4).

Participants', except instructors', second choice is related with the use of Internet that is they use English currently when keeping up with the Internet (item 4) but instructors' second choice emphasized the importance of translating foreign sources (5th item). Translation is highlighted as one of the most important skills because at informal discussions students, engineers and instructors mentioned that departments -at school and at work- might require them to do translation.

To sum up, these results provide useful data for the researcher; for instance, engineers' current use of language may give us an idea about students' target use.

\section{Conclusion}

As mentioned before, the main aim of our research was to find out the language needs of Electric-Electronics Engineering students. The analysis of E-E Engineering students' needs described in this study has revealed that there are discrepancies among participants. For example, when E-E Engineering students were asked their purpose of learning English, they estimated as the most important purpose that having a good knowledge of English will provide them language benefits such as finding a better job, getting better salary and promotion or simply visiting foreign countries. The instructors believe also that Electric-Electronics engineering students learn English for individual benefits.

On the other side, engineers' preferences were not similar with those of the students' and instructors' when we compared the responses for the purpose of learning English. 25\% of the engineers were more interested in the global side of English. They emphasized the essentialness of English in the area of engineering and learn English because it is a universal language. Hutchinson and Waters (1987:6) mention that English is the key to the international currencies of technology and commerce and advocated the global face of English as lingua franca. Language learners require English as 
Uşak Üniversitesi Sosyal Bilimler Dergisi

$2013,6 / 3$

A. KAHRAMAN

a means of furthering their specialist education or as a means of efficiently performing a social working role as a scientist, technologist, technician, etc (Mackay and Mountford, 1978:6). In this case, language learning is not only a local but also a global need.

As the second most important purpose, students highlighted the point that English is very necessary for engineering area when their opinion about the purpose of learning English was asked. This part of the study indicates that there is a need to develop language skills for E-E Engineering students for use within professional setting.

In the second section of the research, participants were asked which language skills they would like to have mastered the most before their graduation (Question 14). Students' upper most desire is to speak English fluently. Nearly all of the engineers agree on the above-mentioned item, so their uppermost choice is also speaking. When the instructors were encountered with the same question, they stated the belief that the students should be able to speak English fluently but on the other hand they emphasized the importance of translation. Most observers would agree that scientific and technical knowledge is communicated through printed documents. To get this knowledge, people should be able to read thoroughly and do a "relevant" translation. Most of the students secondary choice is related with reading skills, namely they would like to read newspapers, magazines, books and papers in English.

Furthermore, when the participants were asked what their present linguistic lacks were, students and engineers again pointed out the lack of their speaking skill in the target language. As highlighted rightly by Bosher ( 2002:67) such information is important for understanding the learning needs of each student in class, their strengths as well as areas of greatest need Thus, participants were also asked about the language skills which they intend to use in their professional lives in the future. Most of the students believe that they will mostly need speaking skills in their vocational fields. That is, the students are certain about the insufficiency of oral practice in English.

However, engineers and instructors do not seem to share the same opinion. Their upper most need is stated as "reading and comprehending" the publications in English. This view is parallel with the literature since 
Uşak Üniversitesi Sosyal Bilimler Dergisi

$2013,6 / 3$

A. KAHRAMAN

Walsh (1982:143) claims that most observers would agree that scientific and technical knowledge is communicated mainly through printed documents: scientific texts, science textbooks, research papers, technical manuals, and technical handbooks. Additionally, engineers highlighted also the lack of translation ability from foreign sources. Translation is highlighted as one of the most important skills because at informal discussions students, engineers and instructors mentioned that departments -at school and at work- might require them to do translation.

In conclusion, all the participants were certain about the need of language for specific purposes. Additionally, they were also certain about the need of English for occupational purposes (EOP). That is; students, engineers and content course teachers felt the need of instructing in ESP.

\section{Pedagogical Implications}

New developments in educational psychology also contributed to the rise of ESP, by emphasizing the central importance of the learners and their attitudes to learning. Learners were seen to have different needs and interests, which would have an important influence on their motivation to learn and therefore on the effectiveness of their learning. This lent support to the development of courses in which relevance to the learners' needs and interests was paramount (Hutchinson and Waters, 1987:8-11).

It is very important to spot linguistic needs of learners before entering the classroom and begin to instruct only relying some kind of experience. That is not a bad idea but much worst thing is not to realize that such kinds of theories are the starting point of investigating learners' worldview. As teachers of English language, we can trust our experiences but we are not able to foresee every kind of need, especially future needs of learners. We hope that the findings of this study, with others in the literature of applied linguistics, have concluded very useful data for language teachers and course designers to train more successful language learners. Consequently, this study can be used for further studies where similar circumstances occur which requires a needs assessment.

\section{References}


Uşak Üniversitesi Sosyal Bilimler Dergisi

$2013,6 / 3$

A. KAHRAMAN

Akar, N. Z. (1999). A needs analysis for the freshman reading course at middle east technical university. Bilkent University, Ankara.

Berwick, R. (1989). Needs assessment in language programming: from theory to practice. In: Johnson, R.K. The second language curriculum. (p. 48-62). Cambridge: Cambridge University Press.

Bosher, S., Smalkoski, K. (2002). From needs analysis to curriculum development: Designing a course in health-care communication for immigrant students in the USA. English for Specific Purposes, 21, pp.59-79.

Brinley, G. (1989). The role of needs analysisin adult esl programme design. In: Johnson, R.K. The second language curriculum. Cambridge: Cambridge University Press, pp.63-78.

Dresdner, M.P. (1981). Teaching scientific English. English Teaching Forum, Vol. 13, 3-4.

Ertaş, G. (1998). A Modular ESP course design for the upper-intermediate learners of English at the Faculty of Medicine at Gazi University. Doktora Tezi, Gazi Üniversitesi, Ankara.

Ertit, A. (1999). Needs analysis for the students of economics, business management and finance departments: ESP Courses at Afyon Kocatepe University. Anadolu University, Eskişehir.

Hutchinson, T; Waters, A. (1987). ESP- A learning-centered approach London: Cambridge University Press.

Jordan, R.R. (1997). English for academic purposes: a guide and resource book for teachers. London: Cambridge University Press.

Kormos, J. et al. (2002). Language wants of English majors in a nonnative context. System. 30, p.517-542.

Lutoslawska, J. (1981) Reading Technical English. English Teaching Forum, 1(3), 247-9.

Mackay, R.; \& Mountford, A.J. (1978) English for specific purposes: A case study approach. London: Longman.

Nunan, D. (1999). Second languageteaching and Learning. Boston: Heinle and Heinle publishers. 
Uşak Üniversitesi Sosyal Bilimler Dergisi

$2013,6 / 3$

A. KAHRAMAN

Okçu, T. (1986). An ESP Syllabus design for freshman year of food engineering Department at Hacettepe University, Yüksek Lisans Tezi, METU, Ankara.

Öner, E. (1983). An approach to ESP curriculum design for Turkish electricity authority, Yüksek Lisans Tezi, METU, Ankara.

Özdamar, K. (1999). Paket programlar ile istatistiksel veri analizi (çok değişkenli analiz): SPSS - minitab. Ankara: Kaan Kitabevi.

Pişiren, H. (1996). A needs analysis for anadolu university civil aviation students' ESP courses. Yüksek Lisans Tezi, Anadolu Üniversitesi, Eskişehir.

Robinson, P. C. (1991) ESP today: A practitioner's guide. New York: Prentice Hall.

Salem, M. M. (1986). An ESP syllabus design for students of civil engineering department at Al-Fatih University in Libya. Yüksek Lisans Tezi, METU, Ankara.

Seçen, B. (2001). A needs analysis: The feasibility of a collaboration between mechnical \& electric-electronics engineering departments and yadim for the instruction of ESP. Yüksek Lisans Tezi, Çukurova Üniversitesi, Adana.

Selinker, L. (1979). On the use of informants in discourse analysis and language for specialized purposes. IRAL, Vol.17, No:3, pp. 215.

Walsh, V. (1982). Reading scientific texts in English. English Teaching Forum, Vol. 20, No.3, p. 143-47.

Wiriyachitra, A. (1982). A scientific reading program. English Teaching Forum, 20 (3) pp. 148-151. 